Journal of Science Education Research

Journal homepage: www.journal.uny.ac.id/jser

\title{
The Design of Local Wisdom-Based Science Learning on Pressure Materials in Junior High School
}

\author{
Aulia Eka Putra1 ${ }^{1}$ Jufrida $^{2}$, Haerul Fathoni ${ }^{3}$, Fibrika Rahmar Basuki ${ }^{*}$ \\ 1,2,3 Study Program of Physic Education, Universitas Jambi, Jambi, Indonesia \\ ${ }^{4}$ Study Program of Physic Education, UIN Sulthan Thaha Saifuddin Jambi, Jambi, Indonesia \\ Corresponding Author. Email: fibrikabika@yahoo.com
}

\section{Keywords: \\ Ethnoscience, \\ Local wisdom, \\ Science learning}

\begin{abstract}
The lesson plan is an important aspect that determines the success of learning in the classroom. Teachers must design learning that can relate the material being studied to the daily lives of students, for example, is through integrated local wisdom into science learning. The study aimed to develop a science learning set of local wisdom based on pressure materials in Junior High Schools. The research was research and development and used a 4D development model (Define, Design, Development, and Disseminate). The subjects were material experts, media experts, and science teachers of junior high school. The instrument was a validation sheet of the learning set. Qualitative data were analyzed descriptively, and quantitative data were analyzed using descriptive statistics. This research produces a science learning set of local wisdom-based on pressure materials in junior high schools, consisting of syllabus, lesson plans, assessments, student worksheets, teaching materials, remedial and enrichment programs. The results of expert validation obtained a score of 89.60 with an excellent category. The results of the science teacher assessment were 92.38 with excellent category. In sum, the science learning set of local wisdom based on pressure material in junior high schools was valid and feasible to improve the understanding of science concepts.
\end{abstract}

C2021 JSER. Universitas Negeri Yogyakarta

\section{INTRODUCTION}

Science is an exact lesson that learns rational and objective knowledge about the universe and all the components (Siagian and Susanto, 2012). Technological advances and changes in job skills occurred in the 21 st century, made critical thinking skills more important than ever. Every person, who learns in the 21 st century, must possess critical thinking skills, knowledge, and digital literacy skills, information literacy, information and communication technology (Jagodziński \& Wolski, 2015). It means that association in the science learning system, starting at primary to secondary levels aiming to improve critical thinking skills needs to be well-designed and implemented.

Design of learning is a process to influence students to adapt to their environment and creating changes within the student. However, the learning designs today, made either by teachers or the world of education are closer to opinions of unable to describe the nature of learning and learning comprehensively. Dolong (2005) states that teaching is one of the most important parts of education, referring to broader and diverse concepts, then education must be carried out with a clear, complete, and comprehensive plan.

Based on the preliminary study conducted at SMPN 7 Muaro Jambi found out that the design of the learning set made by the teachers was only for a formality purpose. As the result, teaching and learning processes are different or do not follow the design of learning devices, such as the syllabus, lesson plans in which contain learning formulas such as books, videos, power points, or other devices to support the teaching and learning process.

A process of learning and teaching will occur in education. Aprida Pane (2017) suggests determining the goal of learning before teaching and learning activities. Learning is a change in behavior as a result of individual interaction with the environment, while teaching is a conscious activity 
carried out by the teacher to convey or deliver information to students. The education system in Indonesia has several levels, such as Elementary School (SD), Junior High School (SMP), and Senior High School (SMA).

According to Astalini et, al (2018), Science subject has a contribution to building students to become a generation that has a scientific attitude towards the environment and their lives. But, science is often considered scary or difficult by students, and the rest like these subjects. Listyawati (2012) states that science learning combines various concepts such as earth, space, chemistry, biology, and has the potential to enrich the experience and increase the competence of students in understanding the natural surroundings. The diagnostic tests have been conducted to SMPN 7 Muaro Jambi and showed $63.9 \%$ of students are difficult or unable to integrate the local wisdom into science learning. Another finding showed the preference of students' learning styles, such as 92.3\% of students like visual learning styles, 55.9\% of students like audio learning styles, and $61.9 \%$ of students like kinesthetic learning styles. In short, not all students have the same learning style, but the learning activity will be easier to understand by students when uses the appropriate learning design.

Several studies have discussed science learning and associated it with local wisdom to make them more interesting and innovative learning. The learning design developed was integrated with Jambi local wisdom. Local wisdom definition takes from the dictionary, which consists of two words "wisdom" and "local". Then, local wisdom may define as a wise local idea that is followed or obeyed by community members (Prasetyo, 2013). Jufrida, et al (2018) argue that local wisdom serves to make people use their minds in acting or responding to an event or phenomenon. And, people or communities will be wise in behaving and acting.

Moreover, Sartini (2004) states that the function of local wisdom may define as social meaning. This means local wisdom may have a function for the development of human resources, such as manifested in traditional ceremonies. Besides social meaning, local wisdom might also mean ethics and morals. Useful and valuable local wisdom is developed due to the need to live, maintain, and life-pattern following the situation, conditions, abilities, and values that are lived in the community concerned (Njatrijani, 2018). Based on the previous explanation, the study aimed to develop a science learning set of local wisdom-based on pressure materials.

\section{METHOD}

The study used a research and development methods to develop a science learning set of local wisdom on pressure material. The development used a 4-D development model, consisting of 4 stages, including define, design, develop, and disseminate. However, this study only did three stages, including define, design, and develop. At the development stage, media expert validation was invited out to determine the media feasibility. The subjects were material experts, media experts, and science teachers at SMP 7 Muaro Jambi. The data analysis technique used descriptive static. Nasution (2017) defines descriptive statistics as a statistical section regarding data presentation, data collection, determination of statistical values, making diagrams or descriptions, where data is presented in the easy way to understand form. The score of the analysis was then analyzed using the following formula:

\section{Percentage $=\mathrm{x} 100$}

After that, it continued to data interpretation to obtain a conclusion on the development of a science learning set of local wisdom on pressure materials in Junior High School. The data category was excellent, good, fairly good, not good, and bad.

Table 1. Criteria for categories

\begin{tabular}{ccc}
\hline No & Category & Interval \\
\hline 1 & Excellent & $81-100 \%$ \\
2 & Good & $61-80 \%$ \\
3 & Fairly Good & $41-60 \%$ \\
4 & Not Good & $21-40 \%$ \\
5 & Bad & $0-20 \%$ \\
\hline
\end{tabular}

Riduwan \& Sunarto (2010)

\section{RESULT}

The development aimed to add references and insights for teachers on integrated science. The development focused on integrated science learning set and Jambi local wisdom on pressure material. This development process used a 4D development model but was only limited to development. The stages were carried out in structured stages, including:

\section{Define}

The define stage consists of 5 steps, namely early-late analysis, student analysis, task analysis, concept analysis, and analysis of instructional objectives. The define stage aimed to determine the instructional requirements by conducting analysis. Also, this stage carried out an analysis on core competencies, basic competencies, learning objectives, and developed scientific concepts so that the module followed the syllabus on Permendikbud (Regulation of Ministry of National Education). 
The first analysis, the early-late analysis aimed to find out the basic problems in the development of a learning set of local wisdom. Facts and alternative solutions, at this stage, were presented to determine the steps in developing an appropriate product of the local wisdom-based learning set.

The second analysis, Student analysis was the stage of studying the characteristics, abilities, and experiences of students at school which was used as a reference in determining the appropriate model, approach, and method.

The third analysis, task analysis was a collection of procedures to determine the content of teaching materials. Task analysis is used to determine the set goal of competencies in learning using the product.

The fourth analysis, concept analysis aimed to analyze the concepts. The concepts in a KD (Basic Competence) are associated with other KD. Identifying, detailing, and systematically compiling relevant concepts were based on the initial-late analysis. In the end, this analysis is used as the basis for determining the learning objectives.

And, analysis of instructional objectives used to formulate the results of task analysis and concept analysis as indicators of achievement of learning outcomes. A series of indicators of achievement of learning outcomes was the basis in preparing the design of learning devices.

\section{Design}

The design stage consisted of 4 steps, namely the preparation of reference tests, media and format selection, and initial design. The purpose of the design stage was to design the prior form of the science learning set. The stages consisted of:

\section{a. Preparation of reference tests}

The test was based on student analysis and learning objectives. The test is a measuring tool to measure the changes in behaving or acting among students after teaching and learning activities.

\section{b. Media Selection}

Media selection was a way of identifying the learning delivery process that is relevant to the material characteristics. The media was chosen to adapt with student analysis, concept analysis, and task analysis. It aimed to assist students in achieving the core competencies and basic competencies. Based on the preliminary study, $63.9 \%$ of students find difficulty in integrating local wisdom and science learning. Moreover, based on the perspective of students' learning styles, $92.3 \%$ of students like the kinesthetic learning style. And, the interviews with science teachers at SMPN 18 Jambi City, showed that students more often used conventional learning than local wisdom as there was no local wisdom-based learning set. Also, many teachers just knew that local wisdom could be associated with physics subjects. But, the learning set has not been associated with the object of local wisdom. In fact, the government has also informed and encourage teachers to further develop learning examples that are associated with the surrounding conditions, especially the Jambi area, and the pressure material on physics subjects.

c. Format selection

Learning a set of local wisdom-based on pressure material in class VIII of Junior High School was designed with the following criteria. First, the paper size was A4 paper $(21 \mathrm{~cm}$ x 29.7 $\mathrm{mcm}$ ) and presented in portrait form. Second, the margin format was normal or $2.54 \mathrm{~cm}$ margin (right, left, top, and bottom). Third, it used Times New Roman font. And, the font size was $14 \mathrm{pt}$.

\section{d. Preliminary design}

At this stage, a learning set had been developed, including a cover, preface, table of contents, syllabus, lesson plans, student worksheet, teaching materials, and assessment sheets. But, the learning set was still a prototype. Nevertheless, this prototype was validated by material experts and media experts, as well as teachers. The learning set consists of a syllabus and lesson plans that are completed with the worksheet, teaching materials, and assessments sheet. The content structure of the learning set was presented in table 2:

Table 2. Structure of Learning Device Set

\begin{tabular}{cll}
\hline No & & \multicolumn{1}{c}{ Sub Bab } \\
\hline 1 & Cover \\
2 & Preface \\
3 & Table of Content \\
4 & Syllabus \\
5 & Lesson Plan (Full) \\
6 & Online- Lesson Plan (One Page) \\
7 & Offline-Lesson Plan (One Page) \\
8 & Appendix \\
9 & Appendix 1. Students Worksheet \\
& a. $\quad$ Worksheet of Solid Pressure \\
& b. $\quad$ Worksheet of hydrostatic pressure \\
& c. $\quad$ Worksheet of Archimedes law \\
& d. $\quad$ Worksheet of Pascal law \\
& e. $\quad$ Worksheet of gas pressure \\
& f. $\quad$ Worksheet of blood pressure \\
& g. $\quad$ Worksheet of osmosis \\
& h. $\quad$ Worksheet of transport tissue \\
10 & Appendix 2. Material \\
& 1. $\quad$ The concept of substance pressure \\
& 2. $\quad$ Pressure of solids \\
& 3. $\quad$ Pessure of the liquid \\
& 4. $\quad$ Pressure of Gas \\
& Appendix 3. Assessment \\
& 1. Attitude & 2. Knowledge
\end{tabular}


Aulia Eka Putra, Jufrida, Haerul Fathoni, Fibrika Rahmar Basuki/ JSER 2021, 5(2), 31

3. Skills

12 Appendix 4. Remedial

1. Program of remedial

2. Remedial.

\section{Development}

The develop stage aimed to produce products of the local wisdom-based learning set. The stage was also a form of the implementation of define and design stages. The validation of the study was only limited to expert validation, which aimed to determine the product feasibility.

\section{A. Experts Validation (Lecturer)}

At this stage, the components of the learning set were validated by material experts, which invited a physics lecturer at UNJA. The obtained data were presented in table 3:

Table 3. Result of Expert Validation

\begin{tabular}{|c|c|c|c|c|}
\hline \multirow[t]{2}{*}{ Component } & \multicolumn{2}{|c|}{ First Validation } & \multicolumn{2}{|c|}{ Second Validation } \\
\hline & Score & Category & Score & Category \\
\hline $\begin{array}{l}\text { Component } \\
\text { of Lesson } \\
\text { Plan }\end{array}$ & $80 \%$ & Good & $95,55 \%$ & Excellent \\
\hline $\begin{array}{c}\text { Formulation } \\
\text { of Indicators } \\
\text { \& Learning } \\
\text { Objectives }\end{array}$ & $73,33 \%$ & Good & $83,33 \%$ & Excellent \\
\hline $\begin{array}{c}\text { Selection of } \\
\text { Material }\end{array}$ & $66,67 \%$ & Good & $83,33 \%$ & Excellent \\
\hline $\begin{array}{l}\text { Learning } \\
\text { Method }\end{array}$ & $80 \%$ & Good & $90 \%$ & Excellent \\
\hline $\begin{array}{l}\text { Activity of } \\
\text { Learning }\end{array}$ & $75 \%$ & Good & $91,67 \%$ & Excellent \\
\hline $\begin{array}{c}\text { Selection of } \\
\text { Learning } \\
\text { Resource }\end{array}$ & $78,33 \%$ & Good & $83,33 \%$ & Excellent \\
\hline $\begin{array}{c}\text { Assessment } \\
\text { of Learning } \\
\text { Outcomes }\end{array}$ & $56,67 \%$ & Enough & $100 \%$ & Excellent \\
\hline Average & 72,86 & Good & $89,60 \%$ & Excellent \\
\hline
\end{tabular}

\section{B. Teacher Validation}

At this stage, the components of the learning set were validated by material experts, which invited a science teacher of Junior High School. The obtained data were presented in table 4:
Table 4. Result of Validation (Teacher)

\begin{tabular}{ccc}
\hline Component & Score & Category \\
\hline Component of Lesson Plan & $96,67 \%$ & Excellent \\
$\begin{array}{c}\text { Formulation of Indicators \& } \\
\text { Learning Objectives }\end{array}$ & $97,50 \%$ & Excellent \\
Selection of Material & $95 \%$ & Excellent \\
Learning Method & $80 \%$ & Good \\
Activity of Learning & $92,5 \%$ & Excellent \\
$\begin{array}{c}\text { Selection of Learning } \\
\text { Resource }\end{array}$ & $95 \%$ & Excellent \\
$\begin{array}{c}\text { Assessment of Learning } \\
\text { Outcomes }\end{array}$ & $90 \%$ & Excellent
\end{tabular}

$\begin{array}{lll}\text { Average } & 92,38 & \text { Excellent }\end{array}$

The development stage is carried out to produce a product of a learning set of local wisdombased in pressure material. The developed products were validated by material experts and media experts, as well as teachers. The purpose of the validation was to determine the feasibility level of the product before being tested in the field. This validation was carried out by 3 material experts, 3 media experts, and 2 teachers. The validation process was carried out 2 times. The components validated by the material expert were the feasibility and the presentation/display of the material/content. While the components validated by the media expert were the language and graphics.

Valid is a requirement for learning sets. The validator who assesses was an expert, competent, and also understands the design of the learning set, and able to provide suggestions for improving the learning sets. The suggestions given by the validator were used in improving the prototype. And, it resulted in the second prototype of the learning sets.

The learning sets have been validated by expert validators using an assessment instrument. The validation was carried out twice. After the first validation, the expert gave suggestions for improving the learning sets. Then, a revision of the product was made following the validator's suggestion. After the product has been through the revision stage, the expert assesses the product for the second time using instruments of assessment. The feasibility of the product was; the syllabus of $92.22 \%$, lesson plans of $90.99 \%$, students worksheet of $90.93 \%$, multiple-choice questions of $98.89 \%$, and essay questions of $97.77 \%$. Based on the validation result of the feasibility, the developed product of the learning set was valid or feasible. 


\section{CONCLUSION}

The particular research produces a science learning set of local wisdom-based on pressure materials in junior high schools, consisting of syllabus, lesson plans, assessments, student worksheets, teaching materials, remedial and enrichment programs. The results of expert validation obtained a score of 89.60 with an excellent category. The results of the science teacher assessment were 92.38 with excellent category. In sum, the science learning set of local wisdom-based on pressure material in junior high schools was valid and feasible to improve the understanding of science concepts. Science learning tools based on local wisdom on stress material in junior high school are declared valid and suitable to be used to improve understanding of science concepts. Science teachers could use these learning sets in the classroom. This research was still limited to learning sets products, so it needs further research to determine the effect of learning sets on attitudes, knowledge, and skills.

\section{REFERENCES}

A'yun, Q. 2019. Pengembangan perangkat pembelajaran model inside outside circle berbasis kearifan lokal Madura untuk melatih kemampuan komunikasi matematis. S1 Skripsi. Surabaya: universitas islam negri sunan ampel Surabaya.

Abonyi, O. S., Achimugu, L., Njoku, Adibe. M. I. 2014. Innovations In Science and Technology Education: A Case for Ethnoscience Based Science Classrooms.International Journal of Scientific Engineering Research, 5 (1).

Aprida Pane, M. D. 2017. Belajar dan Pembelajaran. Jurnal Kajian Ilmu-ilmu Keislaman.hal : 333352.

Astalini, dkk. 2018. Identifikasi Sikap Implikasisosial Dari IPA, Ketertarikan Menambah Waktu Belajar IPA, Dan Ketertarikan Berakhir Di Bidang IPA Siswa SMP Se-Kabupaten Muaro Jambi. Jurnal Tarbiyah: Jurnal Ilmiah Pendidikan. Vol.7. No.2.93.

Barathayomi, W., \& Rahcmawati, D. 2016. Designing English for Specific Purpose Syllabus for Editing Course. The Journal of English Language Studies, 1(2): 95-104.

Dove, Michael R. 2006. Indigenous People and Environmental Politics. Annu. Rev. Anthropol,. 35, 191-208.

Hadi, W. P., Ahied, M.. 2017. Kajian Etnosains Madura Dalam Proses Produksi Garam Sebagai Media Pembelajaran IPA Terpadu. Jurnal Rekayasa, 10 (2), 79-86.
Helmi, T., Munjin, R. A., \& Purnamasari, I. 2016. Kualitas Pelayanan Publik Dalam Pembuatan Izin Trayek Oleh DLLAJ Kabupaten Bogor. Jurnal GOVERNANSI. 2 (1) : 47-59.

Hidayati, Deny. 2016. Memudarnya Nilai Kearifan Lokal Masyarakat Dalam Pengelolaan Sumber Daya Air.Jurnal Kependudukan Indonesia, 11 (1), 39-48.

Jagodziński, P., \& Wolski, R. (2015). Assessment of Application Technology of Natural User Interfaces in the Creation of a Virtual Chemical Laboratory. Journal of Science Education and Technology, 24(1), 16-28.

Jufrida, Basuki, F. R., Pratiwi, D. R. 2018. Potensi Kearifan Lokal Alat Tangkap Ikan Tradisional (Tangkul) di Danau Sipin Kota Jambi Sebagai Sumber Belajar Sains. Jurnal Edufisika, 3 (1).

Jufrida, Basuki, F. R., Rahma, S. 2018. Potensi Kearifan Lokal Geopark Merangin Sebagai Sumber Belajar Sains di SMP. Jurnal Edufisika, 3 (1), 1-15.

Jufrida, dkk. 2019. Analisis Faktor yang Mempengaruhi Hasil Belajar IPA dan Literasi Sains di SMP Negeri 1 Muaro Jambi. Edufisika: Jurnal Pendidikan Fisika, 4(2). ISSN: 2477-7935.

Listyawati, M. 2012. pengembangan perangkat pembelajaran IPA terpadu di SMP. Journal of Innovative Science Education, 61-69.

Peraturan Menteri Pendidikan dan Budaya No. 66 Tahun 2013.

Peraturan Menteri Pendidikan dan Kebudayaan No. 22 Tahun 2016 tentang Standar Proses Pendidikan Dasar dan Menengah.

Peraturan Menteri Pendidikan Nasional Republik Indonesia Nomor 23 tahun 2006 tentang Standar Kompetensi Lulusan untuk Satuan Pendidikan Dasar dan Menengah.

Prasetyo, Z. K. 2013. Pengembangan Sains Berbasis Kearifan Lokal. Seminar Nasional Fisika dan Pendidikan Fisika.

Prastowo, A. (2014). Pengembangan Bahan Ajar Tematik. Jakarta: Kencana Prenamedia grup.

Saputra, G.A.S. 2013. Enhacing Kocak Wisdom Through Local Content Of Elementary School In Java, Indonesia .Proceeding of the Global Summits on Education.

Sari, R., Harjianto, Wahyuni, S. 2018. Pengembangan kearifan lokal kopi pada pokok bahasan usaha dan energi di SMP. Jurnal pendidikan fisika, vol.7 No. 1 .

Sartini. 2004. Menggali Kearifan Lokal Nusantara Sebuah Kajian Filsafat. Jurnal Filsafat, (2).

Sartini. 2004. Menggali Kearifan Lokal Nusantara Sebuah Kajian Filsafat. Jurnal Filsafat, (2).

Siagian H, Susanto I. 2012. Pengaruh Strategi Pembelajaran Genius Learning Terhadap 
Hasil Belajar Fisika Siswa. Jurnal pendidikan fisika. Vol.1. No.2. 4-5.

Thiagarajan, S., Semmel, D. s., \& Semmel, M. I. (1974). Instructional Development for Training Teachers of Exceptional Children. National Center for Improvement Educational System, Washington D.C.

Tokath, A. M., \& Kesli, A. 2009. Syllabus: how much does it contribute to the effective communication with the students?. Procedia Social and Behavioral Sciences 1, 1491-1494.

Tresnawati, Nailah. 2018. Pembelajaran Sains Berbasis Kearifan Lokal Dalam Upaya Peninggkatan Konaservasi Lingkungan Pada Mahasiswa PGSD di Batik Tulis Ciwaringin Cirebon. Jurnal Pendidikan Guru MI, 5 (1), 69-82. 